\title{
Factors Related To Hypertension Management Efforts In Female Workers At Bringharjo Traditional Market Yogyakarta
}

\author{
Indah Wijayanti ${ }^{1}$, Indriani ${ }^{1}$ \\ ${ }^{1}$ Program Pascasarjana Kebidanan Universitas 'Aisyiyah Yogyakarta \\ Jalan Ringroad Barat No.63, Mlangi Nogotirto, Gamping, Sleman Yogyakarta \\ Email: wijayaindah7@gmail.com
}

\begin{abstract}
Abstrak
Hipertensi adalah keadaan tekanan darah di pembuluh darah meningkat secara kronis. Wilayah kota Yogyakarta jumlah penduduk yang memiliki tekanan darah tinggi atau hipertensi mencapai 7.464 jiwa, menyebutkan bahwa hipertensi pada penduduk usia > 15 tahun lebih banyak terjadi pada Perempuan (63,96\%) dibanding Laki-laki (36,04\%) (Profil Kesehatan Tahun 2014 Kota Yogyakarta). Untuk mengetahui faktor resiko yang berhubungan dengan upaya manajemen hipertensi pada pekerja wanita di Pasar Tradisional Bringharjo. Penelitian observasional analitik dengan pendekatan cross sectional,Populasi penelitian ini seluruh pekerja wanita di Pasar Beringharjo sebanyak 4.140 orang. Teknik pengambilan sampel menggunakan teknik Simple Random Sampling yaitu 365 orang. Alat pengumpulkan data adalah kuesioner. Data dianalisis menggunakan uji chi square. Faktor-faktor yang berhubungan dengan upaya manajemen hipertensi meliputi tingkat tekanan darah nilai $p=0,049$, umur nilai $p=0,000$, pendidikan nilai $p=0,000$, riwayat keluarga $p=0,000$, akses pelayanan $p=0,167$, kepemilikan asuransi $p=0,171$, sumber informasi $p=0,118$ dan pengetahuan $p=0,010$. Ada hubungan antara tingkat tekanan darah, umur, pendidikan, riwayat keluarga dan pengetahuan dengan upaya manajemen hipertensi. Sedangkan akses pelayanan kesehatan, kepemilikan asuransi dan sumber informasi tidak ada hubungan dengan upaya manajemen hipertensi. Ada hubungan tingkat tekanan darah, umur, pendidikan, riwayat keluarga dan pengetahuan dengan manajemen hipertensi di Pasar Tradisional Bringharjo, namun tidak ada hubungan akses pelayanan kesehatan, kepemilikan asuransi, dan sumber informasi, dengan manajemen hipertensi responden di Pasar Tradisional Bringharjo. Hasil penelitian ini diharapkan dapat digunakan sebagai tambahan referensi dan bagi responden yang belum sadar dengan manajemen hipertensi untuk melakukan pemeriksaan rutin dan minum obat secara teratur.
\end{abstract}

Kata kunci: hipertensi, faktor, manajemen hipertensi

\begin{abstract}
Hypertension is a condition of blood pressure in blood vessels increases chronically. Yogyakarta has a population of high blood pressure or hypertension reaches until 7,464 people, stating that hypertension in population aged $>15$ years is more common in women (63.96\%) than men (36.04\%) (Year Health Profile 2014 Yogyakarta City). To determine the risk factors associated with hypertension management efforts in female workers at Bringharjo Traditional Market. An observational analytic study with a cross sectional approach. The population of this study is all female workers at Bringharjo Market with quantities of 4,140 people. The sampling technique uses Simple Random Sampling technique that is 365 people. The data collection tool is a questionnaire. The data were analyzed using chi square test. Factors related to hypertension management efforts included blood pressure level $p=0.049$, age $p=0.000$, education $p=0,000$, family history $p=0,000$, service access $p=0.167$, insurance ownership $p=0.171$, information sources
\end{abstract}


$p=0.118$ and knowledge $p=0.010$. There is a relationship between blood pressure level, age, education, family history and knowledge with hypertension management efforts. While health services access, insurance ownership and information sources have no relationship with hypertension management efforts. There is a relationship between blood pressure level, age, education, family history and knowledge with hypertension management at Bringharjo Traditional Market, but there is no relationship between health services access, insurance ownership, and information sources, with respondents of hypertension management at Bringharjo Traditional Market. The results of this study are expected to be used as additional references and for respondents who are not yet aware of hypertension management to carry out routine checks and take medication regularly.

Keywords: hypertension, factors, hypertension management

Article info:

Article submitted on April 01, 2020

Articles revised on May 12, 2020

Articles received on June 09, 2020

DOI: $h$ ttp://dx.doi.org/10.21927/jnki.2020.8(2).141-151

\section{INTRODUCTION}

WHO (World Health Organization) data around the world around 972 million people or $26.4 \%$ of the earth's inhabitants suffer from hypertension, of 972 million people with hypertension, 333 million are in developed countries and 639 are in developing countries, including Indonesia (2).

According to Vilma E. Irazola (2016) hypertension is the most important factor in prevention of cardiovascular disease. There are 7.6 billion deaths due to hypertension in each year. There are several countries that suffer from hypertension, namely $54.9 \%$ in South Africa, $52.5 \%$ in China, $49.9 \%$ in Kenya, $45.4 \%$ in Argentina, 44.1\% in Uruguay, 42.3\% in Pakistan, $39.9 \%$ in Chile, $32.5 \%$ in India, $19.2 \%$ in Peru. The prevalence of hypertension is increasing. Nowadays, in many countries the prevalence of hypertension increases with lifestyle changes such as smoking, obesity, physical activity, and psychosocial stress. At present hypertension affects more than 800 million people worldwide. Approximately $10-30 \%$ of adult population in almost all countries experience hypertension. The survey results in Asia shows the prevalence of hypertension was occupied by India (40\%),
Germany $(60 \%)$ and Indonesia ranked 7 th in Asia. WHO estimates that the prevalence of hypertension is more than $20 \%$ of the world's , In Indonesia there are 5 provinces with high prevalence of hypertension, namely North Sulawesi $15.0 \%$, South Kalimantan $13.1 \%$, Yogyakarta Special Region $12.8 \%$, Central Sulawesi $11.6 \%$, and Gorontalo $11.1 \%$ (4).

Government programs in overcoming the magnitude of challenges in controlling non-communicable diseases and risk factors, the central government designed the Healthy Community Movement (GERMAS) (4).

Rasulullah sallallaahu 'alayhi wa sallam said,

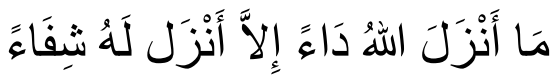

"It is Allah who give a disease, but He will also give a cure for the disease" (H.R. Bukhari).

BPS data 2013 shows that 114 million people are workers, or $48 \%$ of the total Indonesian population of 237.64 million people. Of that number, 68.4 million (60\%) work in informal sector, namely independent, micro, and small scale businesses, and 45.6 million (40\%) are in medium and large scale businesses. Informal 
workers with large numbers and occupational safety and health risks they had to face need to be fostered and provided with health services, one of them is through the development and utilization of Occupational Health Efforts Posts (Pos UKK). Occupational Health Efforts Post (UKK) is an occupational health effort for informal workers resources for the community. Those activities include promotive, preventive, and simple treatments that are first aid in accidents and first aid in diseases. Emphasis on promotion and preventive efforts are to change the workers' behavior to reduce or eliminate the risk of accidents and occupational diseases, and efforts to improve workers' health (9).

According to the Yogyakarta's Health Profile data year 2015, the hypertension sufferers in Kulonprogo Regency in all age groups reach 48,929 people and Bantul Regency 44,066 people. Based on the report of the Integrated System of Non-Communicable Diseases at Puskesmas (STP PTM) of 256,586 Yogyakarta's residents, it is known that the number of hypertension sufferers of all age groups is 32,860 people and $>15$ years old with the number of patients visit to the Puskesmas and blood pressure screening measurements examination reach 40,363 (15.73\%). From these, it is known that high blood pressure (hypertension) sufferers are 7,464 (18.49\%). Yogyakarta has a population of high blood pressure or hypertension reaches until 7,464 people, stating that hypertension in population aged $>15$ years is more common in women $(63.96 \%)$ than men $(36.04 \%)(11)$.

\section{Research Objectives}

General purpose: To determine the risk factors associated with hypertension management efforts in female workers at Bringharjo Traditional Market.
Specific purpose : Knowing the relationship of age with the hypertension management efforts of female workers at Bringharjo Traditional Market, Knowing the relationship of education to the hypertension management efforts of female workers at Bringharjo Traditional Market, Knowing the relationship of knowledge with the hypertension management efforts of female workers at Bringharjo Traditional Market, Knowing the relationship of family history with the hypertension management efforts of female workers at Bringharjo Traditional Market, Knowing the relationship between health service access with hypertension management efforts of female workers at Bringharjo Traditional Market, Knowing the relationship of health insurance ownership with hypertension management efforts of female workers at Bringharjo Traditional Market, Knowing the relationship of information about hypertension with hypertension management efforts of female workers at Bringharjo Traditional Market.

\section{MATERIALS AND METHODS}

This research is an observational analytic study with cross sectional approach. The population of this study is all 4,140 people female workers at Bringharjo Market. Sampling technique uses simple random sampling of 365 people. The collecting data to determine hypertension management efforts in female workers is a questionnaire. The technique used in the validity test of this study is "Pearson product moment" correlation. Reliability test uses the Cronbach Alpha technique.

This research is an observational analytic study with cross sectional approach, which is a research that aims to explain the relationship between variables and hypothesis testing. The cross sectional approach is a research design by measuring or observing at the same time (once in a while) (11). 


\section{RESULT AND DISCUSSIONS}

\section{Univariate Analysis}

\section{Respondents' Characteristics}

Based on the table 1 above, the most respondents who experienced hypertension were 214 people, namely 59 Hypertension Degree I (16.2\%), 74 Hypertension Degree II (20.3\%), and 81 Hypertension Degree III (22.2\%). Hypertension is a disease of all diseases. Hypertension usually becomes a factor that causes the emergence of several other diseases such as heart and kidney failure that can lead to death. Someone who affected hypertension will be difficult to recover completely, so that hypertension management efforts is one of the most appropriate ways to keep blood pressure under control.

Table 1. Frequency Distribution of Respondent Characteristics at Bringharjo Traditional Market

\begin{tabular}{|c|c|c|c|}
\hline \multicolumn{2}{|c|}{ Respondent Characteristics } & \multirow{2}{*}{$\begin{array}{c}\mathbf{F} \\
151\end{array}$} & \multirow{2}{*}{$\begin{array}{c}\% \\
41,4\end{array}$} \\
\hline Blood & a. Normal & & \\
\hline \multirow{3}{*}{ Pressure } & b. Hypertension Degree I & 59 & 16,2 \\
\hline & c. Hypertension Degree II & 74 & 20,3 \\
\hline & d. Hypertension Degree III & 81 & 22,2 \\
\hline \multirow[t]{4}{*}{ Age } & a. $30-39$ years old & 24 & 6,6 \\
\hline & b. $40-49$ years old & 68 & 186 \\
\hline & c. $50-59$ years old & 123 & 33,7 \\
\hline & d. $\geq 60$ years old & 150 & 41,4 \\
\hline \multirow[t]{5}{*}{ Education } & a. Not educated & 77 & 21,1 \\
\hline & b. Primary School & 145 & 39,7 \\
\hline & c. Junior High School & 59 & 16,2 \\
\hline & d. Senior High School & 76 & 208 \\
\hline & e. University & 8 & 2,2 \\
\hline \multicolumn{2}{|l|}{ Total } & 365 & 100 \\
\hline
\end{tabular}

The table above shows that the respondents' characteristics based on the respondents age are mostly at the age of $\geq 60$ years which is 150 people (41.4\%). Whereas the respondents' characteristics based on the most education are in primary school as many as 145 people $(39.2 \%)$.

\section{Family History}

From the table above known that the most respondents who do not have any family history of hypertension are 256 people (70.1\%).
Table 2. Frequency Distribution of Family History Respondent at Bringharjo Traditional Market

\begin{tabular}{lcc}
\hline Family History & $\boldsymbol{f}$ & $\boldsymbol{\%}$ \\
\hline Yes & 109 & 29,9 \\
No & 256 & 70,1 \\
\hline Total & 365 & 100 \\
\hline
\end{tabular}

Source: Primer Data 2017

\section{Health Service Access}

Based on the table above, it is known that the most respondents with access to health services at near distance ( $<15$ minutes) are 225 people $(61.6 \%)$.

Table 3. Frequency Distribution of Health Service Access Respondents at Bringharjo Traditional Market

\begin{tabular}{lcc}
\hline Health Care Access & $\boldsymbol{f}$ & $\boldsymbol{\%}$ \\
\hline Far away ( $>60$ minutes) & 42 & 11,5 \\
Medium (31-60 minutes) & 98 & 26,8 \\
Near (<15 minutes) & 225 & 61,6 \\
\hline Total & 365 & 100 \\
\hline
\end{tabular}

Source: Primer Data 2017

\section{Insurance Ownership}

The table above shows that respondents who had health insurance are 196 people $(53.7 \%)$.

Table 4. Frequency Distribution of Health Insurance Ownership Respondents at Bringharjo Traditional Market

\begin{tabular}{lcc}
\hline Health Insurance Ownership & F & \% \\
\hline Have & 196 & 53,7 \\
Do not have & 169 & 46,3 \\
\hline Total & 365 & 100 \\
\hline
\end{tabular}

Source: Primer Data 2017

\section{Information Sources}

Based on the table above it is known that majority respondents receive information about hypertension from health workers as many as 192 people $(52.6 \%)$.

\section{Knowledge}

Table 6 shows that majority respondents at Bringharjo Market had good category of knowledge in rate of 278 people $(76.2 \%)$. 
Table 5. Frequency Distribution of Hypertension Respondent Information Sources at Bringharjo Traditional Market

\begin{tabular}{lcc}
\hline Information Sources & $\mathbf{F}$ & $\%$ \\
\hline Media & 89 & 24,4 \\
Social Media & 19 & 5,2 \\
Health Workers & 192 & 52,6 \\
Friends & 44 & 12,1 \\
Others & 21 & 5,8 \\
\hline Total & 365 & 100 \\
\hline
\end{tabular}

Source: Primer Data 2017

Table 6. Frequency Distribution of Respondent Knowledge at Bringharjo Traditional Market

\begin{tabular}{lcc}
\hline Knowledge & $\boldsymbol{f}$ & $\%$ \\
\hline Good & 278 & 76,2 \\
Average & 55 & 15,1 \\
Poor & 32 & 8,8 \\
\hline Total & 365 & 100 \\
\hline
\end{tabular}

Source: Primer Data 2017

\section{Hypertension Management}

It is known that respondents who have high category of hypertension management are 217 people $(59.5 \%)$.

\section{Bivariate Analysis}

Based on the data above, it is known that the respondents who have low category
Table 7. Frequency Distribution of Respondent Hypertension Management at Bringharjo Traditional Market

\begin{tabular}{lcc}
\hline Hypertension Management & $\boldsymbol{f}$ & \% \\
\hline High & 217 & 59,5 \\
Average & 74 & 20,3 \\
Low & 74 & 20,3 \\
\hline Total & 365 & 100 \\
\hline
\end{tabular}

Source: Primer Data 2017

hypertension management are 21 people (5.8\%), while the respondents with high management are respondents who do not have hypertension in rate of 97 people (26.6\%). Based on the chi square calculation the significance value of $p$-value is $0.049(p<0.05)$.

It is known that the age of the respondents is 30-39 years with average category of hypertension management are 7 people $(1.9 \%)$, while the age of 60 years with high category hypertension management are 73 people (48.7\%). Based on the chi square calculation the significance value of $p$-value is $0,000(p<0.05)$. It means that there is a relationship between respondents' age and hypertension management.

The results show that the respondents who had higher education with average hypertension

Table 8. Cross Tabulation of Respondent Characteristics Relationship with Hypertension Management Efforts at Traditional Market Bringharjo

\begin{tabular}{|c|c|c|c|c|c|c|c|c|c|c|}
\hline \multirow{3}{*}{ Variable } & \multicolumn{6}{|c|}{ Management } & \multirow{2}{*}{\multicolumn{2}{|c|}{ Total }} & \multirow{3}{*}{$P$ Value } & \multirow{3}{*}{$\mathrm{X} 2$} \\
\hline & \multicolumn{2}{|l|}{ Low } & \multicolumn{2}{|c|}{ Average } & \multicolumn{2}{|c|}{ High } & & & & \\
\hline & $f$ & $\%$ & $f$ & $\%$ & $f$ & $\%$ & $f$ & $\%$ & & \\
\hline \multicolumn{11}{|l|}{ Blood Pressure } \\
\hline Normal & 26 & 7,1 & 28 & 7,7 & 97 & 26,6 & 151 & 100 & \multirow{4}{*}{0,049} & \multirow{4}{*}{12,67} \\
\hline Hypertension Degree I & 12 & 3,3 & 19 & 5,2 & 28 & 77 & 59 & 100 & & \\
\hline Hypertension Degree II & 15 & 4,1 & 18 & 4,9 & 41 & 11,2 & 74 & 100 & & \\
\hline Hypertension Degree III & 21 & 5,8 & 9 & 2,5 & 51 & 14,0 & 81 & 100 & & \\
\hline \multicolumn{11}{|l|}{ Age } \\
\hline 30 - 39 years old & 3 & & 0,8 & & 7 & 1,9 & 14 & 3,8 & \multirow{4}{*}{0,000} & \multirow{4}{*}{32,25} \\
\hline $40-49$ years old & 8 & & 2,2 & & 22 & 13,8 & 38 & 40,4 & & \\
\hline $50-59$ years old & 17 & & 4,7 & & 14 & 3,8 & 92 & 25,2 & & \\
\hline$\geq 60$ years old & 46 & & 12,6 & & 31 & 8,5 & 73 & 20,2 & & \\
\hline \multicolumn{11}{|l|}{ Education } \\
\hline Not educated & 21 & 27,3 & 13 & 16,9 & 43 & 55,8 & 77 & 100 & \multirow{5}{*}{0,000} & \multirow{5}{*}{38,82} \\
\hline Primary School & 31 & 21,4 & 21 & 14,5 & 93 & 64,1 & 145 & 100 & & \\
\hline Junior High School & 10 & 16,9 & 14 & 23,7 & 35 & 59,3 & 59 & 100 & & \\
\hline Senior High School & 12 & 15,8 & 18 & 23,7 & 46 & 60,5 & 76 & 100 & & \\
\hline University & 0 & 0,0 & 8 & 100 & 0 & 0,0 & 8 & 100 & & \\
\hline Total & 74 & 20,3 & 74 & 20,3 & 217 & 59,5 & 365 & 100 & & \\
\hline
\end{tabular}

Source: Primer Data 2017 
Table 9. Cross Tabulation of Research Variable with Hypertension Management Efforts at Bringharjo Traditional Market

\begin{tabular}{|c|c|c|c|c|c|c|c|c|c|c|}
\hline \multirow{3}{*}{ Variable } & \multicolumn{6}{|c|}{ Hypertension Management } & \multirow{2}{*}{\multicolumn{2}{|c|}{ Total }} & \multirow{3}{*}{$P$ Value } & \multirow{3}{*}{$X^{2}$} \\
\hline & \multicolumn{2}{|c|}{ Low } & \multicolumn{2}{|c|}{ Average } & \multicolumn{2}{|c|}{ High } & & & & \\
\hline & $f$ & $\%$ & $f$ & $\%$ & $F$ & $\%$ & $f$ & $\%$ & & \\
\hline \multicolumn{11}{|l|}{ Family History } \\
\hline Yes & 15 & 13,8 & 12 & 11,0 & 82 & 75,2 & 109 & 100 & \multirow{2}{*}{0,000} & \multirow{2}{*}{16,338} \\
\hline No & 59 & 23,0 & 62 & 24,2 & 135 & 52,7 & 256 & 100 & & \\
\hline \multicolumn{11}{|l|}{ Health Care Access } \\
\hline Far away (> 60 minutes) & 9 & 21,4 & 5 & 11,9 & 28 & 66,7 & 42 & 100 & \multirow{3}{*}{0,167} & \multirow{3}{*}{6,471} \\
\hline Average (31-60 minutes) & 22 & 22,9 & 14 & 14,3 & 62 & 63,3 & 98 & 100 & & \\
\hline Near (<15 minutes) & 43 & 19,1 & 55 & 24,4 & 127 & 56,4 & 225 & 100 & & \\
\hline \multicolumn{11}{|l|}{ Insurance Ownership } \\
\hline Have & 33 & 16,8 & 39 & 19,9 & 124 & 63,3 & 196 & 100 & \multirow{2}{*}{0,171} & \multirow{2}{*}{3,532} \\
\hline Do not have & 41 & 24,3 & 35 & 20,7 & 93 & 55,0 & 169 & 100 & & \\
\hline \multicolumn{11}{|l|}{ Information source } \\
\hline Media & 19 & 21,3 & 22 & 24,7 & 48 & 53,9 & 89 & 100 & \multirow{5}{*}{0,118} & \multirow{5}{*}{12,826} \\
\hline Social media & 0 & 0,00 & 6 & 31,6 & 13 & 68,4 & 19 & 100 & & \\
\hline Health workers & 41 & 21,4 & 33 & 17,2 & 118 & 61,5 & 192 & 100 & & \\
\hline Friends & 12 & 27,3 & 6 & 13,6 & 26 & 591 & 44 & 100 & & \\
\hline Others & 2 & 9,5 & 7 & 33,3 & 12 & 57,1 & 21 & 100 & & \\
\hline \multicolumn{11}{|l|}{ Education } \\
\hline Good & 47 & 16,9 & 56 & 20,1 & 175 & 62,9 & 278 & 100 & \multirow{3}{*}{0,010} & \multirow{3}{*}{13,374} \\
\hline Enough & 15 & 27,3 & 15 & 27,3 & 25 & 45,5 & 55 & 100 & & \\
\hline Poor & 12 & 37,5 & 3 & 94 & 17 & 53,1 & 32 & 100 & & \\
\hline Total & 74 & 20,3 & 74 & 20,3 & 217 & 59,5 & 365 & 100 & & \\
\hline
\end{tabular}

Source: Primer Data 2017

management are 8 people (100\%), while respondents who had primary education with high hypertension management are 93 people $(64.1 \%)$. Based on the calculation of the chi square the $p$-value is $0,000(p<0.05)$. It means that there is a relationship between respondent education and hypertension management.

From the data above, it is known that the respondents who have family history of hypertension with low hypertension management are 59 people $(23.0 \%)$, while respondents who do not have family history with high hypertension management are 135 people (52.7\%). With the $p$-value 0,000 there is a relationship between respondents' family history and hypertension management. The respondents who far away from health service access with high hypertension management are 28 people $(66.7 \%)$, while the respondents who near health service access with high hypertension management are 127 people $(56.4 \%)$. There is a significant relationship between the variables of respondents' health service access with hypertension management ( $p$-value 0,000$)$. The result shows that the respondents who had health insurance with low hypertension management are 41 people $(24.3 \%)$, while respondents who had health insurance with high hypertension management are 124 people (63.3\%). Based on the $p$-value 0.171 ( $p>0.05$ ), there is no relationship between respondents' health insurance ownership and hypertension management. It is known that the respondents with low hypertension management are 41 people $(21.4 \%)$ and high hypertension management found in 118 people $(61.5 \%)$ received hypertension information sources from health workers. With $p$-value 0.118 ( $p>0.05$ ) means that there is no relationship between the acquisition of hypertension information sources with hypertension management. The respondents who have good knowledge with low hypertension management are 47 people $(16.9 \%)$, while the respondents who have good knowledge with high hypertension management 
are 175 people (62.9\%). There is a significant relationship between respondents' knowledge and hypertension management $(p=0.010)$.

\section{Discussion}

\section{Relationship of Respondents' Hypertension} with Hypertension Management at Bringharjo Traditional Market

Majority respondents have normal blood pressure with high category of hypertension management in rate of 97 people $(26.6 \%)$, while the respondents category III with low management are 21 people (5.8\%). Research conducted by Singh A et all in India in 2014 shows that the incidence of hypertension was significantly associated with the increase of age. The research has consistently shown a positive relationship between age and blood pressure in various regions that have different geographical, cultural, and socioeconomic characteristics. Blood pressure changes caused by the changes of age are due to the changes in vascular system. The increasing age causes decreased elasticity of blood vessels.

Based on the chi square calculation the significance value of $p$-value is $0.049(p<0.05)$. It means that there is a relationship between respondents' blood pressure and hypertension management.

\section{Relationship of Respondents' Age with Hypertension Management at Bringharjo Traditional Market}

The analysis shows that there is a relationship between the respondents' age and hypertension management at Bringharjo Traditional Market with a significant value 0,000 ( $p$ <0.05). Research conducted by Dwi (2016) shows that the respondents' age is one indicator of hypertension increases. The respondents' age who suffer from hypertension can affect the respondents' awareness in managing hypertension management.
Relationship of Respondents' Education with Hypertension Management at Bringharjo Traditional Market

Based on the results of the study known that majority respondents at Bringharjo Traditional Market who have low education (Primary School) are 145 people (39.7\%). Education is a conscious and planned effort to create an atmosphere of learning and learning process so that students develop their potential actively to have spiritual strength, self-control, personality, intelligence, noble character, and skills needed by themselves, society, held within the territory of Unitary State of Republic Indonesia. The function of this education undergoes a process of specialization and institutions and formal education, which remain related to informal education process outside the school (8).

There is a significant relationship of education variables and hypertension management $(p=0,000)$. Education requires humans to act and fill their lives that can be used to obtain information so that it can improve the quality of life. The higher someone's education, the easier it will be for someone to receive information thereby increasing the quality of life and broadening knowledge.

This study shows that the respondents are in primary school group. The respondents who have high hypertension management are 93 people $(64.1 \%)$. Research conducted by Geo Wahyu, et al (2015) reveals that knowledge about illness does not influenced by the respondents' last education level. Data obtained from this study shows that the respondents who had high level of knowledge reached $85.6 \%$ of the total respondents, which is most respondents did not attend school. This is appropriate with research conducted by Salman T. Shafi and Tahir Shafi (2017) in Punjab Pakistan proves that the majority of respondents who do not attend school have high awareness in managing hypertension by controlling hypertension. 
Knowledge about the diseases experienced in this case, the respondents can obtained from various sources not only from formal education. Counseling activities and direct explanation when the patient is treated, are the alternatives to improve patient knowledge about hypertension. This is what makes the respondents less educated but able to deal with hypertension well compared to the respondents who have higher education but do not have awareness dealing with hypertension as well as desire to continue earn income by trading at Bringharjo Traditional Market.

\section{Relationship of Family History with Hypertension Management at Bringharjo Traditional Market}

This study shows a relationship between family history and management of hypertension with $p$-value $0,000(p<0.05)$. The results of research conducted by Hafiz et al (2016) shows that there is a significant relationship between genetics and the incidence of hypertension. According to Sutanto (2010), it happens because someone who has a family history of hypertension, some of their genes interact with the environment and cause the blood pressure increase. The role of genetic factors in the emergence of hypertension is evidenced by the finding that hypertension is more common in monozygotic twins (one egg) than heterozygotes (different eggs). Patients who have genetic characteristics of primary hypertension (essential) if left naturally without therapeutic intervention, together with their environment will cause their hypertension developed and within about 30 - 50 years the signs and symptoms will arise (7).

The results show that the respondents who did not have a family history were able to do hypertension management with a number of 135 people $(52.7 \%)$. It can be due to the information exchange related to the illness and the danger of hypertension from other parties who suffer from or manage hypertension, so raises the respondents awareness that they do not suffer from similar illnesses that increases and motivates them to be able to manage hypertension properly. While 12 respondents $(11 \%)$ have a family history of hypertension but their hypertension management is sufficient. Low awareness is one of the factors causing this. In fact, for family who have hypertension history (genetic) and heart disease increase the risk of hypertension 2 until 5 times (6).

\section{Relationship of Health Service Access with Hypertension Management at Bringharjo Traditional Market}

Based on $p$-value of 0.131 ( $p>0.05)$, means that there is no significant relationship between access or distance to hypertension management. The result supports the research conducted by Puspita (2016) shows that there is no relationship between affordability of access to health services with pursuance in undergoing hypertension treatment at Gunungpati Puskesmas, Semarang. That is because the most respondents (55\%) claimed they had suffered from hypertension $>5$ years, so that even though the distance and access to health services were easy, they felt fed up with the treatment they were undergoing, so they would come for treatment when they felt a complaint.

\section{Relationship of Health Insurance Ownership with Hypertension Management at Bringharjo Traditional Market}

Based on the results of the study known that most respondents who have Health Insurance are 196 people $(53.7 \%)$. This result illustrates that the health costs of female workers have largely been served by local government. The insurance ownership includes health insurance (ASKES) that is registered by themselves and a health card (a card used to get free health services for poor families, issued by the local government). 
The $p$-value $0.171(p>0.05)$ means that there is no relationship between health insurance and hypertension management. The result supports the research conducted by Puspita (2016) shows that there is no relationship between the health insurance participation with adherence in undergoing hypertension treatment at Gunungpati Puskesmas, Semarang. It can be caused even though the respondent has health insurance, but there are other factors such as time and there is no family supports that help to take the respondent to do health check and treatment, so that the respondents can not do hypertension management as they want. Actually, family members who provide good support and caring attitude to the sufferer have an important role in treatment adherence. The family members attention starting from delivering them to health services, helping to finance medical treatment, reminding them to take medication, are proved to be more obedient to undergo treatment compared to the hypertension sufferers who received less attention from family members (12).

\section{Relationship of Information Sources with Hypertension Management at Bringharjo Traditional Market}

Based on the chi square calculation the significance value of $p$-value is $0.118(p<0.05)$. It means that there is no relationship between health information on hypertension management. Information is one source of knowledge that can be obtained from various sources, such as from health workers, print and electronic media, as well as information from neighbors and relatives. This statement is supported by Susanti, et al, (2012) which states that various kinds of information obtained by the community, especially the problem of hypertension, will be able to increase public knowledge, one of them is the provision of health education.
Relationship of Respondents Knowledge with Hypertension Management at Bringharjo Traditional Market

Based on the results of the study known that the most respondents with good level of knowledge have high hypertension management that is 175 respondents (62.9\%). Knowledge is the impression in the human mind as a result of the use of the five senses. Knowledge is the result of knowing and occurs after people sensing a certain object (23). In addition, according to Long E (2016), who conducted research on hypertension in women aged 40-65 years in Africa showed that good knowledge about hypertension will make people know about how the signs and symptoms will be caused by hypertension. It will eventually increase efforts to prevent hypertension and increase awareness about hypertension management.

There is a significant relationship of hypertension knowledge and management variables with $p$-value 0.010 . The result support the research conducted by Geo Wahyu (2015) which shows that the level of knowledge influences medication adherence by obtaining a value of $p=0.015<\alpha=0.05$. Respondents who have knowledge related to hypertension will have motivation to manage and carry out hypertension management so that they can reduce and improve their health conditions.

The result shows that knowledge is lacked the impact of sufficient management by 3 people $(9.4 \%)$. This is similar to research conducted by Puspa (2015) that out of 48 respondents who have low level of knowledge about hypertension, 35 respondents $(72.9 \%)$ are not compliant in undergoing hypertension treatment.

The respondents who have insufficient knowledge can be caused by they do not have free time to visit or checkup at the health center, beside the time factor, working in the market is an active activity carried out from morning to evening while in general Puskesmas only serve 
until $4 \mathrm{pm}$, so they do not have the opportunity to conduct the checkup. There is a need for attention from Bringharjo market's manager to help female workers to maintain their health by managing to collaborate with nearby health workers, bringing in several assistants for health workers directly for socialization by distributing leaflets about handling hypertension and explaining at a glance so that indirectly able to increase the knowledge of female workers at Bringharjo market.

\section{CONCLUSIONS AND RECOMMENDATIONS}

Based on the results of research and discussion, the following conclusions can be drawn: Respondents who had normal blood pressure with high category of hypertension management are 97 people (26.6). There is a relationship of hypertension with respondents' hypertension management at Bringharjo Traditional Market with $p$-value of $0.049(p<5 \%)$. The age of respondents who are more than 60 years old has a high hypertension management, that is 73 people $(48.7 \%)$. There is a relationship between age and respondents' hypertension management at Bringharjo Traditional Market with $p$-value of $0,000(p<5 \%)$. Respondents who did not have a family history are able to manage hypertension with a high of 135 people $(52.7 \%)$. There is a relationship of family history with respondents' hypertension management at Bringharjo Traditional Market with $p$-value 0,000 $(p<5 \%)$. There is no relationship between health services access with respondents' hypertension management at Bringharjo Traditional Market with $p$-value 0.167 ( $p<5 \%$ ). Although the respondents have health insurance, but there are other factors such as time and there is no family supports that help to lead the respondent to checkup and medication are make the respondent not do hypertension management. There is no relationship of health insurance ownership with hypertension management of respondents at Bringharjo Traditional Market with $p$-value $0.171(p<5 \%)$. There is no relationship between information sources and respondents' hypertension management at Bringharjo Traditional Market with $p$-value $0.118(p<5 \%)$. There is a relationship of knowledge with respondents' hypertension management at Bringharjo Traditional Market. Respondents who have good knowledge are able to manage high hypertension as many as 175 people (62.9\%).

\section{REFERENCES}

1. Adriaansz: The Relationship of Food Consumption with the Occurrence of Hypertension in the Elderly in Manado's Puskesmasranomuut. ejournal Nursing (eKp) Volume 4 Number 1, May 2016.

2. Astianto: The Effect of Job Stress and Workload on the Performance of Surabaya Pdam Employees. Journal of Management Science \& Research Vol. 3 No. 7 (2014).

3. Health Data and Information of Yogyakarta Special Region Province; 2016.

4. Health Department RI. Indonesian Health Profile. Jakarta: Ministry of the Republic of Indonesia. 2009.

5. Dwi. Factors Related to the Level of Hypertension in the Work Area of Demak Community Health Center II. Journals. 2016

6. Hafiz et al. Factors Related to the Occurrence of Hypertension in the Elderly Group in the Work Area of Petan Health Center Upt. 2016.

7. g I of Badung Regency 2016. ISSN: 23031395 E-JOURNAL MEDIKA, VOL. 5 NO.7, JULI, 2016.

8. Ministry of Health of the Republic of Indonesia in 2016.

9. Muhammad, H ,. Weta, I ,. Ratnawati, N. L. K ,. Factors Related to the Occurrence of Hypertension in the Elderly Group in the Working Area of Upt at the Petang I Health Center in Badung Regency 2016. ISSN: 2303-1395 E-JOURNAL MEDIKA, VOL. 5 NO.7, JULI, 2016. 
10. Health Profile of Yogyakarta City 2015.

11. Puspita, Eka: Factors Associated with Compliance with Hypertension Patients Undergoing Treatment. Journals. 2016

12. Rina: Factors That Are Related to the Occurrence of Hypertension in Patients with Inpatients at Sari Mutiara General Hospital, Medan in 2014. Journal of Nursing Scientific Vol. 1, No. 1, February 2015.

13. Salman T. Shafi and Tahir Shafi: A survey of hypertension prevalence, awareness, treatment, and control in health screening camps of rural central Punjab, Pakistan. Journal of Epidemiology and Global Health 7 (2017) 135-140

14. Seedat, Y. K., Rayner, B.L., Vieava, Y.,: Hypertension. Cardiovascular Journal Of Africa Volume 25, No 6, November / December.2014.

15. Situmorang, Easter, R: Factors That Are Related to the Occurrence of Hypertension in Patients with Inpatients at Sari Mutiara General Hospital, Medan in 2014. Journal of Nursing Scientific Vol. 1, No. 1, February 2015.

16. Singh A et all: Prevalence of Hypertension and its Risk Factor among Urban Sikh
Population of Amritsar. IJSR; 3 (3): 827-32. 2014.

17. Susanti, M. T., Suryani, M., \& Shobirun: Effects of Health Education About Hypertension on Knowledge and Attitudes Managing Hypertension in Pandanaran Health Center Semarang. Journals. 2012.

18. Sule, S., Tekin, A., Yunus, E., Ulver, D., Mustafa, A., Sukru, S., Oktay, K., Cetin, T., Enver, H., Sali, C., Sehsuvar, E ,: Changes in hypertension prevalence, awareness, treatment, and control rates in Turkey from 2003 to 2012. J Hypertens. 2016 Jun; 34 (6): 1208-1217.

19. Sukarmin: The Effect of Healing Touch Therapy on Changes in Blood Pressure of Hypertension Patients in Tulakan Village, Donorojo Jepara. Journal of Health "Samodra Sciences” Vol. 07 No. 01, January 2016

20. Wiliam, B. K.,: The prevalence, awareness, and control of hypertension among workers in West Africa: a systematic review. Journals 2015.

21. Notoatmodjo, S. (2007). Promosi Kesehatan dan IImu Perilaku. Jakarta : Rineka Cipta. 